\title{
PENGONTROLAN SUHU, KELEMBAPAN, DAN INTENSITAS CAHAYA PADA KUMBUNG JAMUR DENGAN PENDEKATAN FINITE ELEMENT DALAM PENEMPATAN SENSOR
}

\author{
Willy Tanadi ${ }^{1}$ \\ Program Studi Teknik Elektro Universitas Kristen Maranatha \\ Email : willytanadi4@gmail.com \\ Muliady ${ }^{1}$ \\ Program Studi Teknik Elektro Universitas Kristen Maranatha \\ Email : muliady@eng.maranatha.edu
}

\begin{abstract}
S: The success of harvesting white oyster mushrooms depends on the treatment especially the conditions of temperature, humidity, and light intensity in the mushroom house, the placement of sensors must be precise so it can represent the conditions inside the white oyster mushroom and proper action can be taken. Determination of the location of the sensor point is done using the Finite Element Method approach by dividing the mushroom house into small segments to help analyze the parameters of temperature, humidity, and light intensity inside. The control system uses an ON-OFF hysteresis controller mode. Temperature and humidity sensors (DHT11) are positioned respectively on the left, center, and right side of the mushroom house. Data from DHT11 measurement is processed by NodeMcu V3 microcontroller and then will activate the actuator. The interface (GUI) for monitoring is designed to use Blynk application. The controlled parameters meet the needs of white oyster mushrooms, temperatures of $20-26^{\circ} \mathrm{C}$ with the error $2{ }^{\circ} \mathrm{C}$, humidity $80-90 \%$ with the error $5 \%$, and lighting 200 640lux with the error 10 lux. The control signal can keep the range of parameters maintained.

Keywords: Finite Element Method, Hysteresis ON-OFF controller, NodeMcu V3, DHT11, Light Dependent Resistor, Blynk application
\end{abstract}

ABSTRAK: Keberhasilan panen jamur Tiram Putih tergantung pada perawatan yang diterapkan terutama kondisi suhu, kelembapan, dan intensitas cahaya di dalam kumbung, penempatan sensor harus tepat sehingga sensor dapat mereprensentasikan keadaan di dalam kumbung jamur tiram putih sehingga aksi yang tepat dapat dilakukan. Penentuan letak titik sensor dilakukan dengan menggunakan pendekatan Finite Element Method yaitu membagi kumbung menjadi segmentsegment kecil untuk membantu menganalisis parameter suhu, kelembapan dan intensitas cahaya di dalam kumbung jamur tiram putih. Sistem kontrol menggunakan mode pengontrol ON-OFF hysteresis. Sensor suhu dan kelembapan (DHT11) diposisikan masing-masing pada bagian kiri, tengah, dan kanan kumbung. Data hasil pengukuran DHT11 diolah oleh mikrokontoler NodeMcu V3 yang akan mengaktifkan aktuator di dalam kumbung. Antarmuka (GUI) untuk monitoring parameter yang diamati menggunakan aplikasi Blynk. Parameter yang dikontrol dapat memenuhi kebutuhan jamur tiram putih, yaitu suhu $20-26^{\circ} \mathrm{C}$ dengan error $2^{\circ} \mathrm{C}$, kelembapan $80-90 \%$ dengan error $5 \%$, dan pencahayaan 200-640lux dengan error 10lux. Sinyal kontrol yang dihasilkan mampu menjaga agar range parameter yang dibutuhkan tetap terjaga.

Kata kunci: Finite Element Method, Mode pengontrol ON-OFF hysteresis, NodeMcu V3, DHT11, LDR (Light Dependent Resistor), aplikasi Blynk.

\section{PENDAHULUAN}

$\mathrm{P}$ tani jamur tiram putih di Indonesia masih menggunakan cara konvensional dalam merawat tanaman jamur tiram putih. Umumnya petani menyiram tanaman jamur tiram putih berdasarkan penglihatan petani saja dan terjadi kelebihan atau kekurangan penyiraman sehingga dinilai tidak mempengaruhi pertumbuhan jamur Tiram Putih. Keadaan suhu dan intensitas cahaya juga mempengaruhi pertumbuhan jamur [1].

Terdapat penelitian-penelitian lain yang pernah dilakukan di antaranya Aji Nugroho dkk tentang pengaturan suhu dan kelembapan kumbung jamur dengan merancang sistem pengontrol suhu dan kelembapan sederhana yang diletakkan di dalam kumbung jamur Tiram Putih. Hasil pengujian sistem menunjukkan sistem dapat menjaga kestabilan suhu dan kelembapan kumbung rata-rata $25^{\circ} \mathrm{C}$ dan $60 \%$ dengan setpoint $27^{\circ} \mathrm{C}$ dan $55 \%$ [2]. Penelitian lain oleh Sri Waluyo dkk telah merancang pengendalian suhu dan kelembapan terhadap jamur Tiram Puth secara otomatis berbasis mikrokontroler dan peletakkan sensor di beberapa titik kumbung jamur Tiram Putih. Pengujian sistem dilakukan di ketinggian $215 \mathrm{mdpl}$ dengan setpoint suhu $25-30^{\circ} \mathrm{C}$ dan kelembapan $80-95 \%$. Hasil pengujian menunjukkan sistem mampu menjaga suhu $25,10-30,09^{\circ} \mathrm{C}$ dan kelembapan $64,28-99.90 \%$ di dalam kumbung [3]. Peneliti Anisum, yang meneliti distribusi suhu dan kelembapan kumbung jamur dengan metode Computational Fluid Dynamics (CFD) untuk optimalisasi letak sensor [4]. Penelitian

\footnotetext{
${ }^{1}$ Program Studi Teknik Elektro Universitas Kristen Maranatha
} 
lain oleh Fenny Amelia dkk. menyatakan suhu dan intensitas cahaya mempengaruhi pertumbuhan jamur Tiram [5].

Hasil panen jamur yang baik diperlukan perawatan dan teknik kontrol yang benar. Penempatan sensor harus diperhatikan agar dapat merepresentasikan keadaan kumbung, sehingga dapat memberikan treatment yang benar terhadap jamur Tiram Putih. Dari penelitian-penelitian tersebut dijadikan referensi atau acuan untuk merealisasikan sistem pemantauan dan kontrol untuk menjaga keadaan suhu $\left(20-26^{\circ} \mathrm{C}\right)$, kelembapan $\left(80-90^{\circ} \mathrm{C}\right)$, dan intensitas cahaya (200-640 lux) berbasis Internet of Things (IoT). Hasil pengukuran menunjukkan beberapa titik kumbung memiliki suhu, kelembapan, dan intensistas cahaya yang berbeda karena distribusi parameter tersebut di dalam kumbung tidak merata. Oleh karena itu, penentuan titik-titik penempatan sensor-sensor di dalam kumbung ditentukan menggunakan Finite Element Method (FEM) [6] agar pengukuran oleh sensor dapat mewakili keadaan di dalam kumbung jamur Tiram Putih dan melibatkan tiga variabel yang dikontrol sekaligus yaitu suhu, kelembapan, dan intensitas cahaya [7].

\section{METODOLOGI PENELITIAN}

\section{Kumbung Jamur Tiram Putih}

Kumbung jamur tiram putih dirancang dengan ukuran $1.5 \times 2 \times 2.2$ meter dibangun seperti pada Gambar 1, dengan kerangka menggunakan bahan baja ringan. Dinding kumbung dibangun menggunakan bahan GRC.
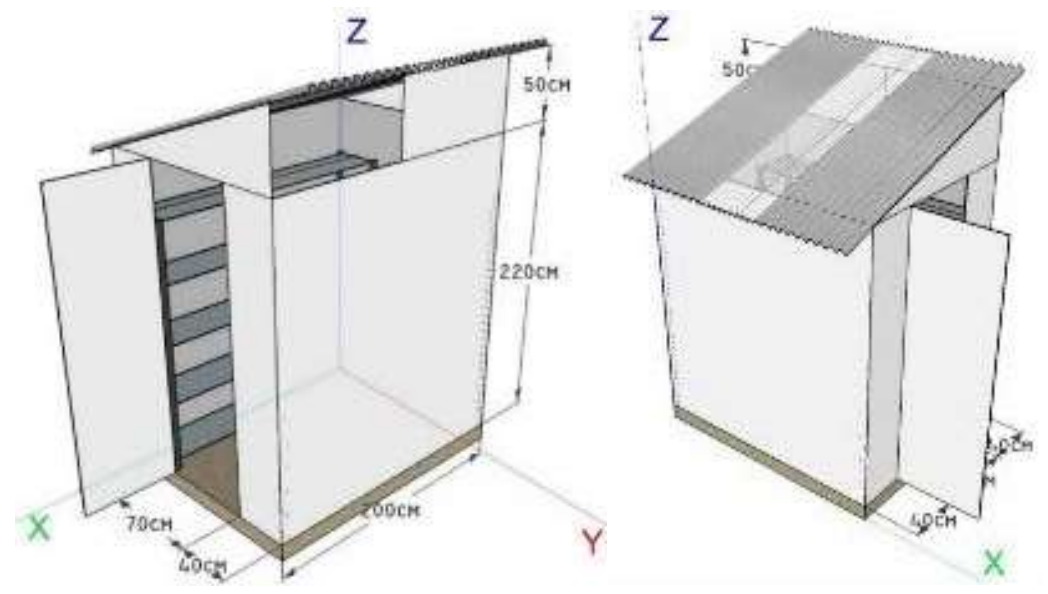

Gambar 1. Kumbung Jamur Tiram Putih

Kumbung jamur tiram putih dibagi menjadi segment-segment kecil dan menghasilkan segment berukuran $50 \times 50 \times 55 \mathrm{~cm}$. Ukuran segment tersebut dianggap cukup representatif untuk dapat dianalisis suhu, kelembapan, dan intesitas cahayanya karena dalam satu segment perubahannya tidak terjadi secara cepat. Pembagian kumbung jamur tiram putih dapat dilihat pada Gambar 2
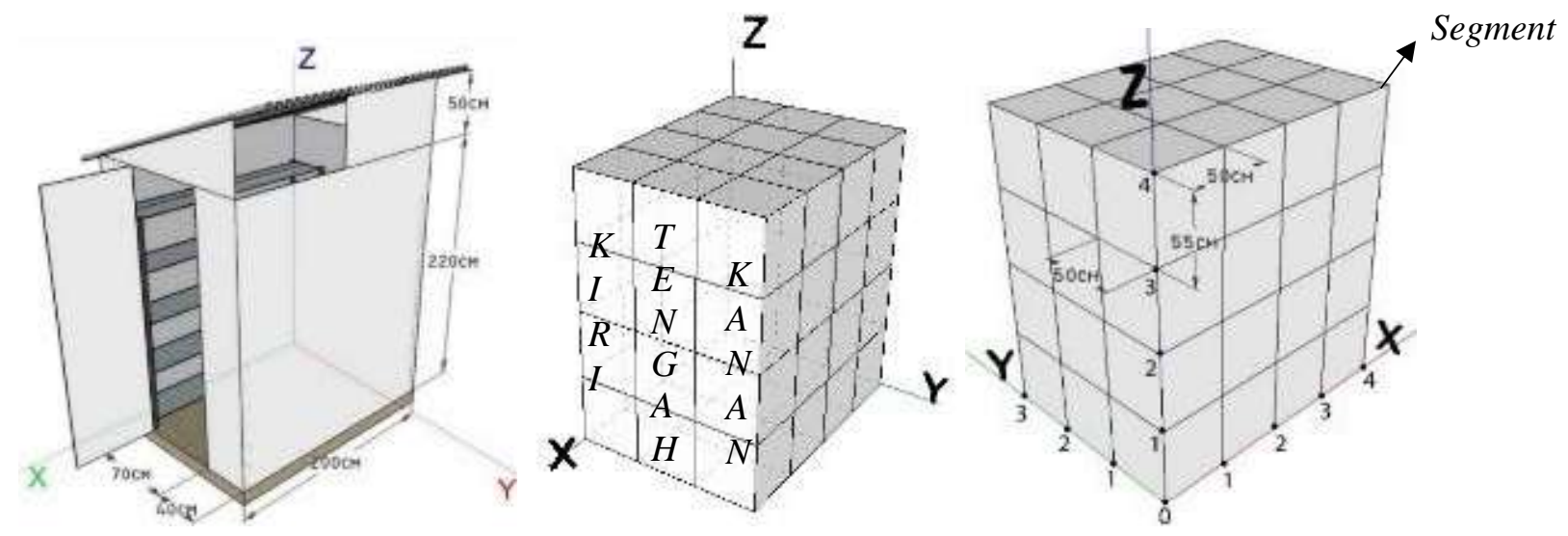

Gambar 2. Pembagian Kumbung Jamur Tiram Putih 
Kumbung jamur tiram putih akan dibagi menjadi 3 bagian, yaitu bagian kiri, bagian tengah, dan bagian kanan mengacu pada Gambar 2. Segment-segment yang terbentuk dari pembagian kumbung jamur tiram putih diukur suhu, kelembapan, dan intensitas cahayanya. Pengukuran dilakukan dalam 2 tahap pengukuran, yaitu :

1. Pagi : jam $09.00-12.00$

2. Siang : jam $13.00-15.00$

Hasil pengukuran masing-masing segment dianalisis yang bertujuan untuk mengamati distribusi suhu, kelembapan, dan intensitas cahaya, guna menentukan posisi letak sensor agar dapat merepresentasikan seluruh keadaan di dalam kumbung.

\section{Posisi Letak Sensor Suhu dan Kelembapan dalam Kumbung Jamur Tiram Putih}

Segment-segment pada bagian kiri, tengah, dan kanan kumbung diukur suhu, kelembapan dan intensitas cahayanya. Dari parameter-parameter yang telah diukur oleh sensor, penentuan daerah yang dapat mewakili setiap bagian kumbung (diwakili oleh bidang kiri, tengah, dan kanan) dilihat dari selisih paling kecil hasil perbandingkan antara rata-rata parameter keseluruhan dari masing-masing bagian kumbung dengan rata-rata parameter per kolom, baik itu dari parameter suhu dan kelembapan. Hasil pengukuran dan rata-rata suhu dan kelembapan kumbung per bagian (kiri, tengah, kanan) dapat dilihat masing-masing pada Tabel 1, Tabel 2, Tabel 3. Daerah yang mewakili bagian kiri kumbung dan posisi sensor dapat dilihat pada Gambar 3, bagian tengah kumbung ditunjukkan pada Gambar 4, dan yang terakhir bagian kanan kumbung ditunjukkan pada Gambar 5.

Tabel 1. Menunjukkan Hasil dan Rata-Rata Pengukuran Suhu dan Kelembapan Bagian Kiri

\section{Kumbung}
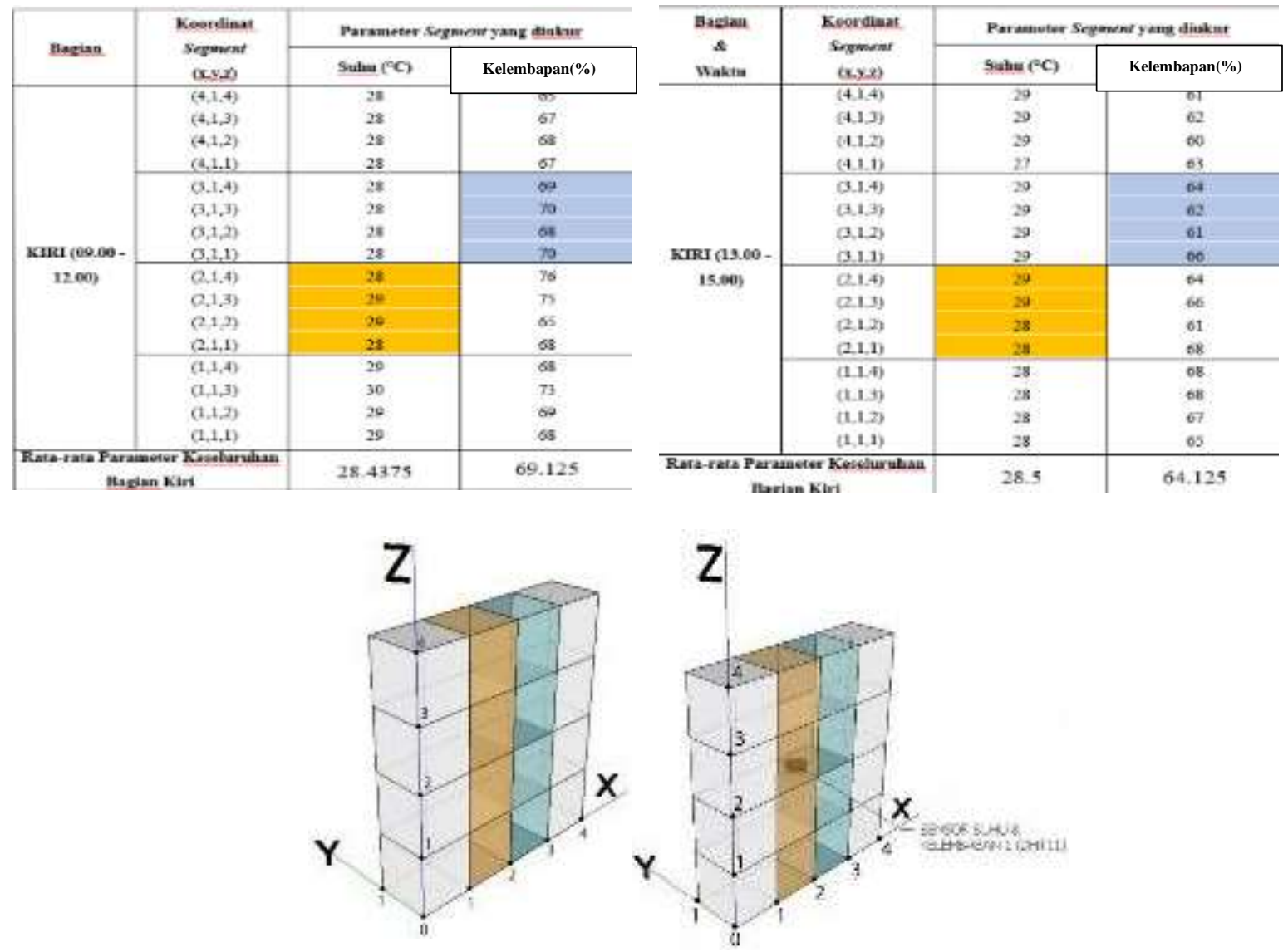

ם Gambar 3. Daerah yang Mewakili dan Posisi Sensor Bagian Kiri Kumbung 
Tabel 2. Menunjukkan Hasil dan Rata-Rata Pengukuran Suhu dan Kelembapan Bagian Tengah

\begin{tabular}{|c|c|c|c|}
\hline \multirow{2}{*}{$\frac{\text { Dlaplan }}{a}$} & \multirow{2}{*}{$\begin{array}{c}\text { Koerntinat } \\
\text { Segment } \\
(\operatorname{sex} x)\end{array}$} & \multicolumn{2}{|c|}{ Parameet Segment yang dinlanr } \\
\hline & & Salun (CO) & Kelembapan $(\%)$ \\
\hline \multirow{16}{*}{$\begin{array}{c}\text { IINGAH } \\
\text { (00.se-12.00) }\end{array}$} & $(4,2+1)$ & 31 & 62 \\
\hline & $(4,2,3)$ & 31 & e4 \\
\hline & $(4,2,2)$ & 31 & 34 \\
\hline & $(4,2,1)$ & 31 & 57 \\
\hline & $(3,2,4)$ & 31 & 66 \\
\hline & $(3,2,3)$ & n2 & 6 \\
\hline & $(3,2,2)$ & 31. & $\$ 7$ \\
\hline & $(9,2,1)$ & 31 & 57 \\
\hline & $(2,2,4)$ & 32 & 68 \\
\hline & $(2,23)$ & 32 & 61 \\
\hline & $(2,2,2)$ & 32 & so \\
\hline & $(2,2,1)$ & 31 & 58 \\
\hline & $(1,2,4)$ & 32 & 59 \\
\hline & $(1,29)$ & 32 & 60 \\
\hline & $(1,2,2)$ & 32 & 57 \\
\hline & $(1,2,1)$ & 31 & 55 \\
\hline \multicolumn{2}{|c|}{$\begin{array}{c}\text { Rasa rata Parnatier Knechuruhas } \\
\text { Ragian Ttegah }\end{array}$} & 31.4375 & 59.8125 \\
\hline
\end{tabular}
Kumbung

\begin{tabular}{|c|c|c|c|}
\hline \multirow{2}{*}{$\begin{array}{c}\text { Basiaa } \\
\text { of } \\
\text { Wakni }\end{array}$} & \multirow{2}{*}{$\begin{array}{c}\text { Koordlisat } \\
\text { segment } \\
(x, y, y)\end{array}$} & \multicolumn{2}{|c|}{ Parameter Segmend yane diskin } \\
\hline & & Saha (C) & Kelembapan(\%) \\
\hline \multirow{16}{*}{$\begin{array}{c}\text { TEVGAII } \\
(1300-15.90)\end{array}$} & $(+2,4)$ & 27 & 74 \\
\hline & $(4,2,3)$ & 27 & 73 \\
\hline & $(+, 2,2)$ & 27 & 72 \\
\hline & $(4,2,1)$ & 27 & 75 \\
\hline & $(3,2,4)$ & 27 & 79 \\
\hline & $0.2 .3)$ & 27 & 75 \\
\hline & 32,20 & 27 & $n$ \\
\hline & 0.215 & 27 & 73 \\
\hline & $0,2,4)$ & 27 & 73 \\
\hline & $(2,2,3)$ & 27 & 71 \\
\hline & $(2,2,2)$ & 27 & $n$ \\
\hline & $(2,2,1)$ & 27 & $\Leftrightarrow$ \\
\hline & $(1,2,4)$ & 27 & 72 \\
\hline & $(1.2 .3)$ & 27 & 75 \\
\hline & $(1,2,2)$ & 27 & 70 \\
\hline & (0.2.1) & $n$ & 70 \\
\hline \multicolumn{2}{|c|}{$\begin{array}{c}\text { Rata rota Parameter Keseluruhat } \\
\text { Bagian Teasah }\end{array}$} & 27 & 72.8125 \\
\hline
\end{tabular}
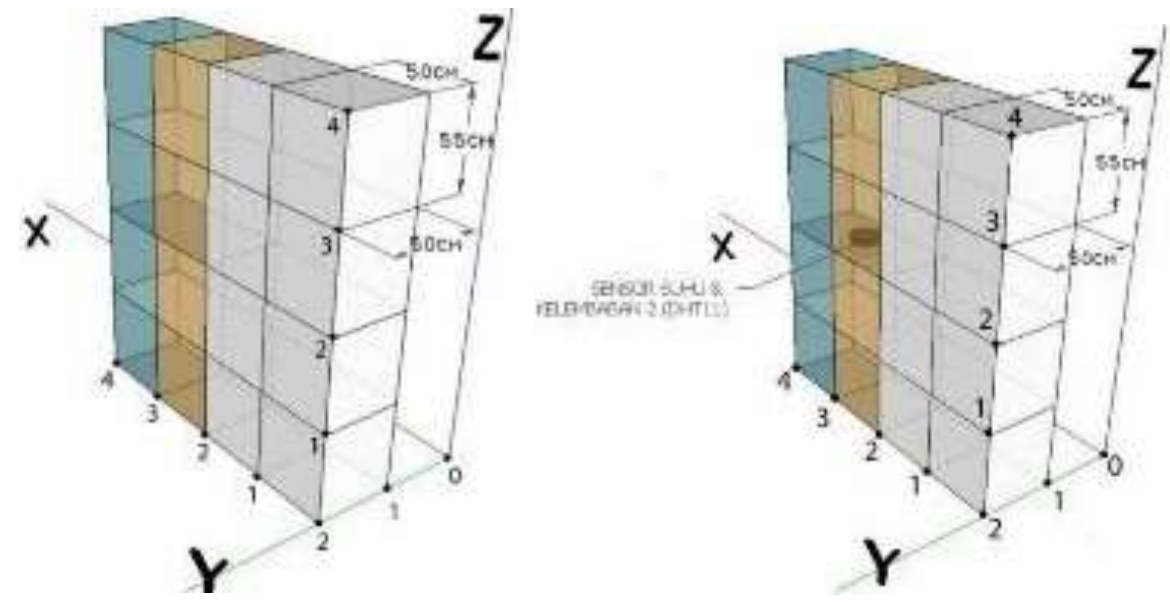

Gambar 4. Daerah yang Mewakili dan Posisi Sensor Bagian Tengah Kumbung

- Tabel 3. Menunjukkan Hasil dan Rata-Rata Pengukuran Suhu dan Kelembapan Bagian Kanan Kumbung

\begin{tabular}{|c|c|c|c|c|c|c|c|}
\hline \multirow{2}{*}{$\begin{array}{c}\text { Bagian } \\
\text { A } \\
\text { Walau }\end{array}$} & \multirow{2}{*}{$\begin{array}{c}\text { Keorifinat } \\
\text { Seguient } \\
(x, y, 2)\end{array}$} & \multicolumn{2}{|c|}{ Parameter Segment yang diukur } & \multirow{2}{*}{$\begin{array}{c}\text { Bapian } \\
\text { \& } \\
\text { Walaw }\end{array}$} & \multirow{2}{*}{$\begin{array}{c}\text { Koerdinat } \\
\text { Segment } \\
(x, y)\end{array}$} & \multicolumn{2}{|c|}{ Paraneter Segenent yang diukur } \\
\hline & & Sehu $\left({ }^{\circ} C\right)$ & Kelembapan $(\%)$ & & & Selhe $\mathrm{CC}$ & Kelembapan(\%) \\
\hline \multirow{16}{*}{$\begin{array}{c}\text { KANaN } \\
(09.00-12.00)\end{array}$} & $(1,3,4)$ & 32 & 88 & \multirow{16}{*}{$\begin{array}{c}\text { KANAN } \\
(23.00-15.00)\end{array}$} & $(4,3,4)$ & 28 & 69 \\
\hline & $(4,3,3)$ & 32 & 61 & & $(+, 3,3)$ & 28 & 6s \\
\hline & $(4,3,2)$ & 32 & 6) & & $(4.3 .2)$ & 28 & 68 \\
\hline & $(4,3,1)$ & 32 & 64 & & $(4,3,1)$ & 27 & 70 \\
\hline & $(3,3,4)$ & 31 & 64 & & $(3.94)$ & 28. & $\omega 3$ \\
\hline & $(3,3,3)$ & 32 & 61 & & $(3,33)$ & 28 & 68 \\
\hline & $(3,3,2)$ & 32 & 61 & & $(3,3,2)$ & 28 & 66 \\
\hline & $(3,3,1)$ & 31 & 62 & & (3.3.1) & 20 & *9 \\
\hline & $(2,3,4)$ & 91 & 68 & & $(2,3,4)$ & 28 & 10 \\
\hline & $(2,3, y)$ & 31 & or. & & $(2,3,3)$ & 28 & 71 \\
\hline & $(2,3,2)$ & 31 & 62. & & $(2,3,2)$ & 20 & sa \\
\hline & $(2,3,1)$ & 30. & 64 & & $(2,3,1)$ & 24 & or \\
\hline & $(1,3,4)$ & 30 & 72 & & $(1.3 .4)$ & 28 & 70 \\
\hline & $(1,3,3)$ & 31 & 72 & & $(1,3,3)$ & 28 & 69 \\
\hline & $(1,3,2)$ & 30 & 67 & & $(1,3,2)$ & 28 & $\Leftrightarrow$ \\
\hline & $(1,3,1)$ & 30 & 67 & & $(1,3,1)$ & & \\
\hline \multicolumn{2}{|c|}{$\begin{array}{c}\text { Rata-rata Parnmeter Keseluruhan } \\
\text { Bagian Kanas }\end{array}$} & 31.125 & 64.5 & \multicolumn{2}{|c|}{$\begin{array}{l}\text { Rata-rata Parameter Keschuruhas } \\
\text { Boxian Kanan }\end{array}$} & 27.9375 & 68.625 \\
\hline
\end{tabular}



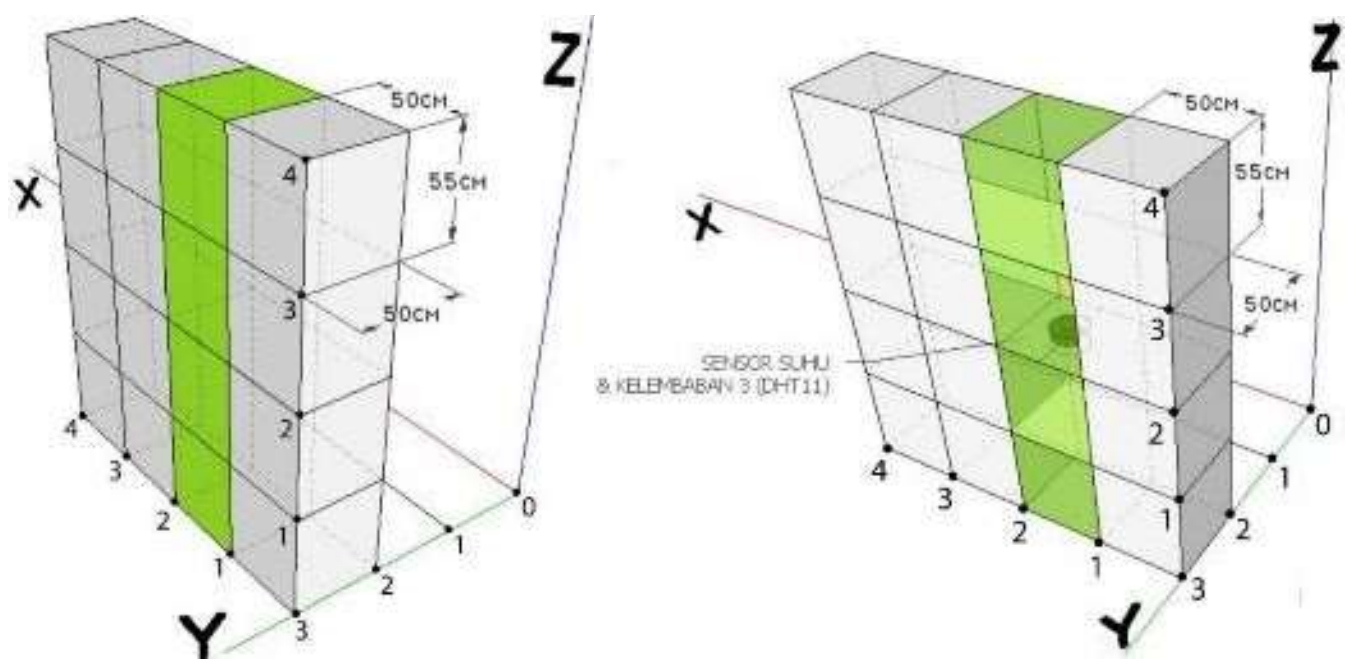

Gambar 5. Daerah yang Mewakili dan Posisi Sensor Bagian Kanan Kumbung

Sensor-sensor DHT11 akan mengukur keadaan di dalam kumbung jamur tiram putih, baik bagian kiri, tengah, dan kanan. Hasil pengukuran tersebut akan mewakili keadaan suhu dan kelembapan bagian kumbung tersebut.

LDR akan diletakkan di bagian tengah antara koordinat $(3,2,2)$ dan $(2,2,2)$ di dalam kumbung jamur tiram putih. Sehingga diharapkan keadaan intensitas cahaya yang diukur dapat mewakili keadaan di segment-segment bagian bawah kumbung jamur tiram putih. Posisi LDR di dalam kumbung dapat dilihat pada Gambar 6.

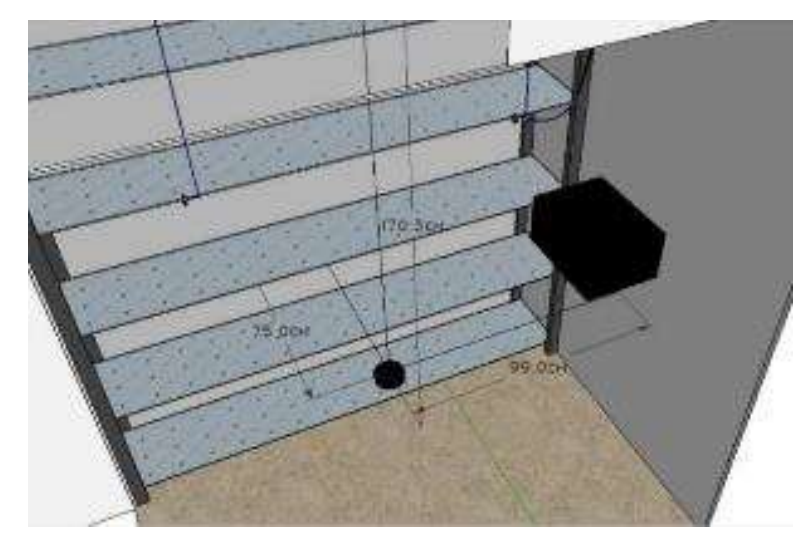

- Gambar 6. Posisi LDR di dalam Kumbung Jamur Tiram Putih.

Hasil pengukuran sensor-sensor (DHT11 dan LDR) kemudian diolah oleh controller (NodeMcu V3). Controller mengatur kerja dari aktuator dan transducer sehingga efek dari kerja aktuator dan transducer akan mempengaruhi keadaan di dalam kumbung. Hasil pengukuran sensor-sensor dikirim oleh controller ke aplikasi Blynk melalui jaringan internet yang ditumpangkan melalui router WiFi. Diagram blok sistem dapat dilihat pada Gambar 7 dan proses kontrol sistem dapat dilihat pada Gambar 8 


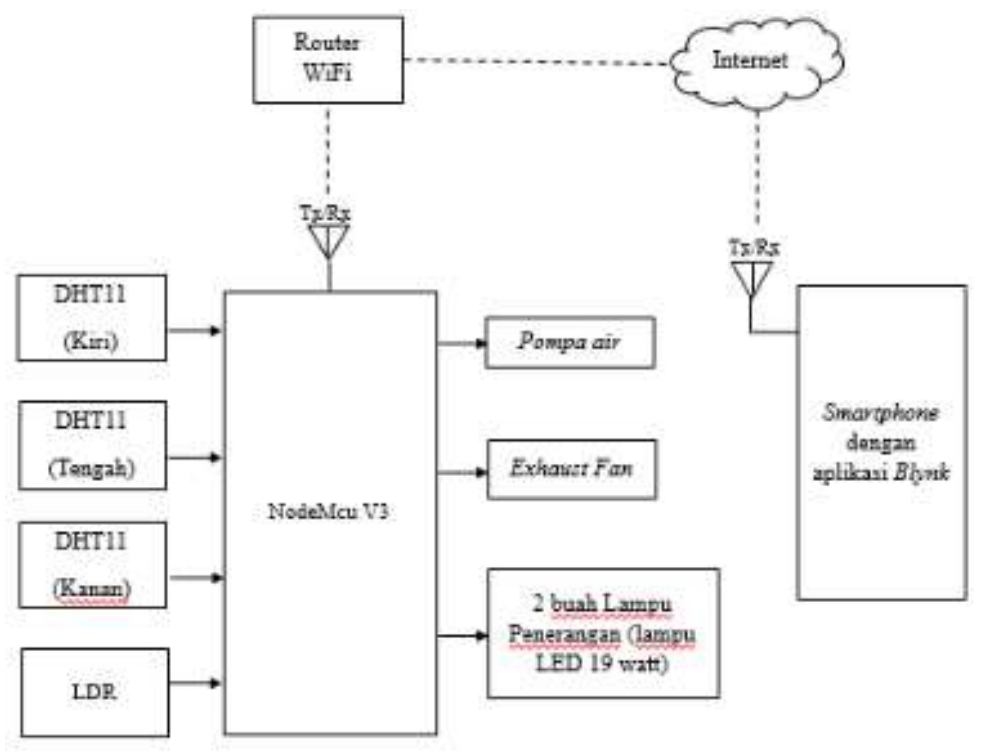

Gambar 7. Diagram Blok Sistem pada Kumbung Jamur Tiram Putih

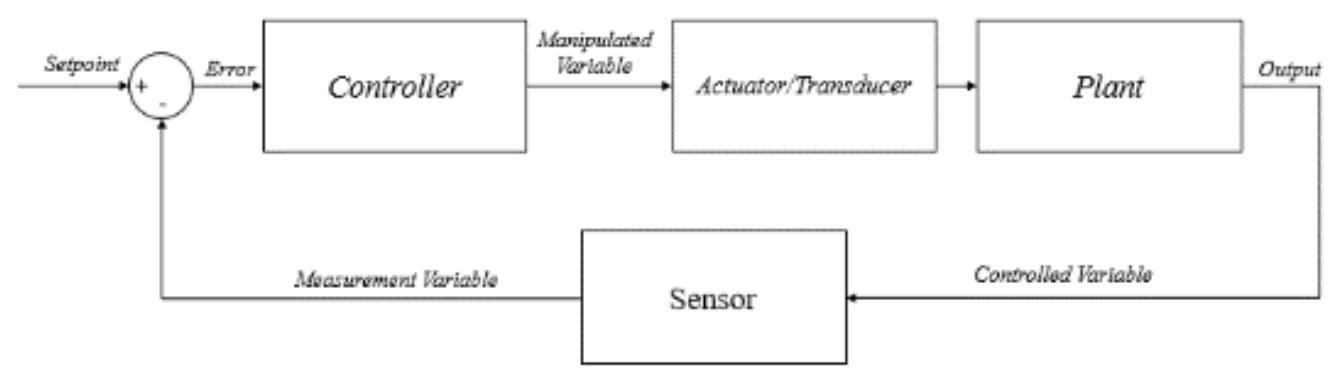

Gambar 8. Proses Kontrol Sistem pada Kumbung Jamur Tiram Putih [6]

Pada Gambar 9 menampilkan kerja sistem. Saat sistem diaktifkan, akan terkoneksi ke jaringan internet. Selanjutnya sensor-sensor akan mulai mengukur keadaan di dalam kumbung. Hasil pengukuran sensor-sensor akan diolah oleh mikrokontroler NodeMcu V3. Ketika suhu bagian kiri, tengah, dan kanan kumbung yang diukur melebihi $26^{\circ} \mathrm{C}$, maka NodeMcu V3 akan memberikan logika $0(L O W)$ pada relay 1 (pompa). Jika kelembapan bagian kiri, tengah, dan kanan kumbung yang diukur kurang dari $80 \%$, maka NodeMcu V3 akan menghasilkan logika 0 (LOW)pada relayl (pompa). Jika salah satu hasil pengukuran sensor DHT11 diantara $23^{\circ} \mathrm{C}-26^{\circ} \mathrm{C}$, maka NodeMcu V3 akan menghasilkan logika 1 (HIGH 3.3V). Intensitas cahaya yang mempengaruhi kumbung jika kurang dari 200 lux, maka NodeMcu V3 akan mengaktifkan lampu penerangan LED. Jika intensitas cahaya berada diantara 200-640 lux atau lebih dari 640 lux, maka NodeMcu V3 akan menghasilkan logika 1 (HIGH 3.3V). 

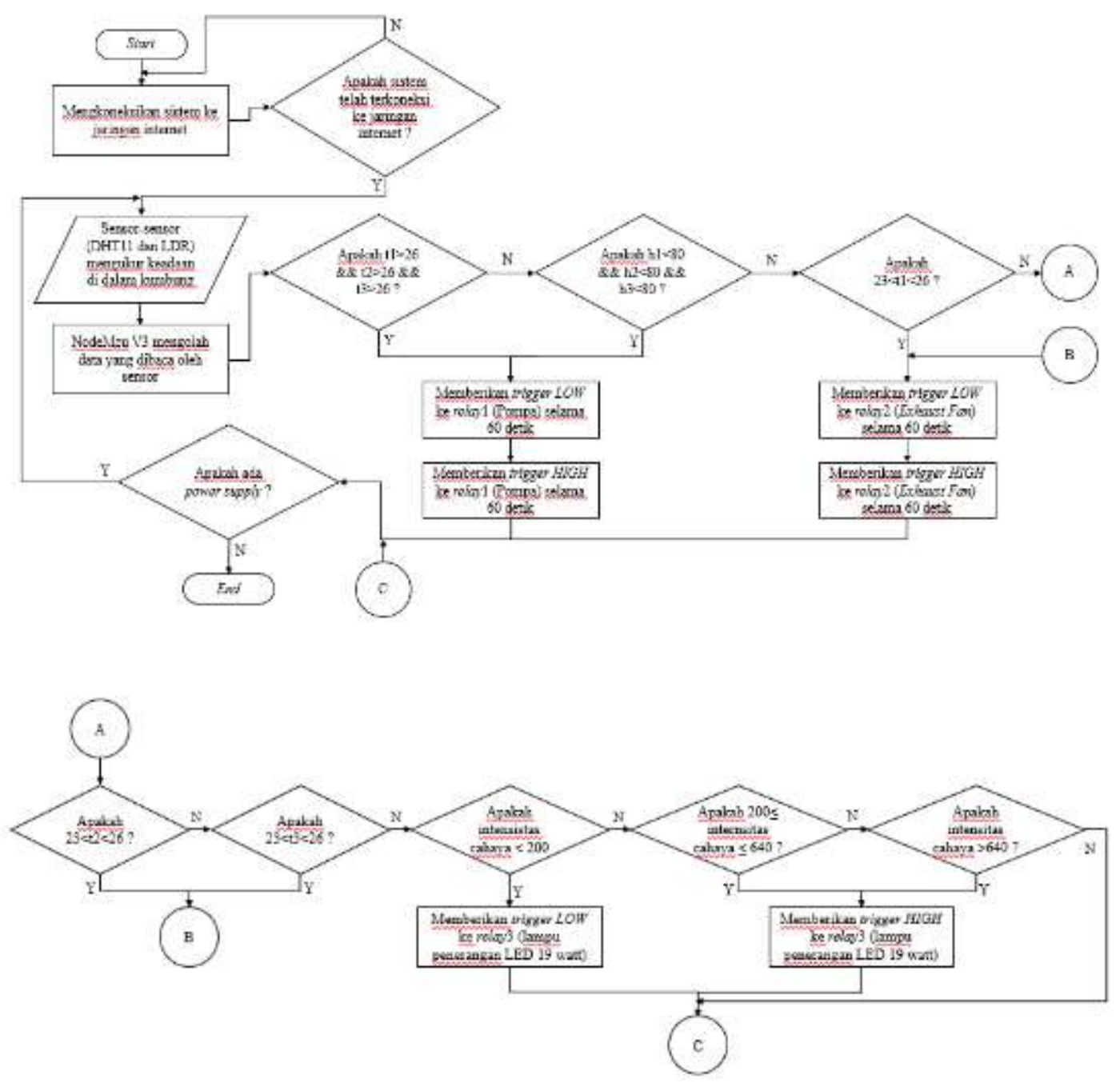

Gambar 9. Flowchart Sistem pada Kumbung Jamur Tiram Putih

\section{Perancangan dan Realisasi Aplikasi Blynk}

Antarmukapada aplikasi Blynk akan berfungsi sebagai antarmuka interface untuk memantau, merekam data dari parameter yang sedang dikontrol. Antarmuka menampilkan keadaan suhu, kelembapan, dan intensitas cahaya melalui displayvalue. Button untuk mengaktifkan sprayer secara manual dirancang jika sewaktu-waktu diperlukan untuk melakukan penyiraman di dalam kumbung jamur tiram putih. Seluruh parameter yang dikontrol termasuk sinyal kontrol ditampilkan dalam bentuk grafik yang dirancang pada antarmuka aplikasi Blynk. Antarmuka aplikasi Blynk dapat dilihat pada Gambar 10. 

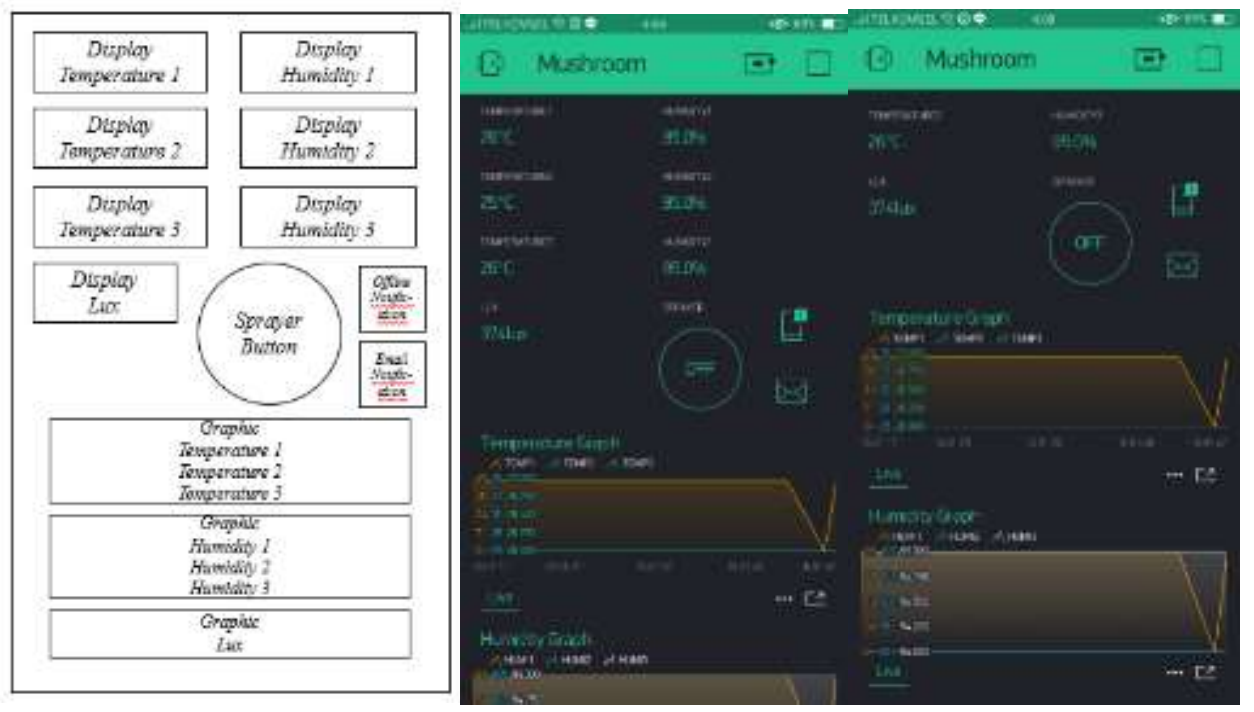

Gambar 10 Platform Splikasi Blynk

\section{HASIL DAN PEMBAHASAN}

Berikut adalah grafik hasil pengujian kinerja sistem dalam menjaga parameter suhu, kelembapan, dan intensitas cahaya kumbung dalam rentang waktu 24 jam. Batas atas setpoint (suhu: $26^{\circ} \mathrm{C}$; kelembapan: $90 \%$ ) ditunjukkan oleh garis biru. Batas bawah setpoint (suhu: $20^{\circ} \mathrm{C}$; kelembapan: $80 \%$ ) ditunjukkan oleh garis hijau. Garis Temp1, Temp2, Temp3 menunjukkan pembacaan suhu oleh sensor yang mewakili masing-masing bagian kiri, tengah dan kanan kumbung. Sedangkan garis Humi1, Humi2, Humi3 menunjukkan pembacaan kelembapan udara oleh sensor yang mewakili masing-masing bagian kiri, tengah, dan kanan kumbung.

Dilihat dari grafik pada Gambar 11, suhu cenderung masuk ke dalam range setpoint yang dibutuhkan oleh jamur tiram putih. Sedangkan kelembapan di dalam kumbung cendrung melebihi batas atas setpoint yaitu di atas $90 \%$. Hal ini terjadi karena pengaruh dari kondisi alam yang mempengaruhi keadaan di dalam kumbung jamur tiram putih. Sinyal kontrol yang dihasilkan baik untuk relayl (pompa) dan relay2 (exhaust fan) berlogika HIGH ( $3.3 \mathrm{~V}$ ) yang berarti relay dalam kondisi OFF atau normally close.

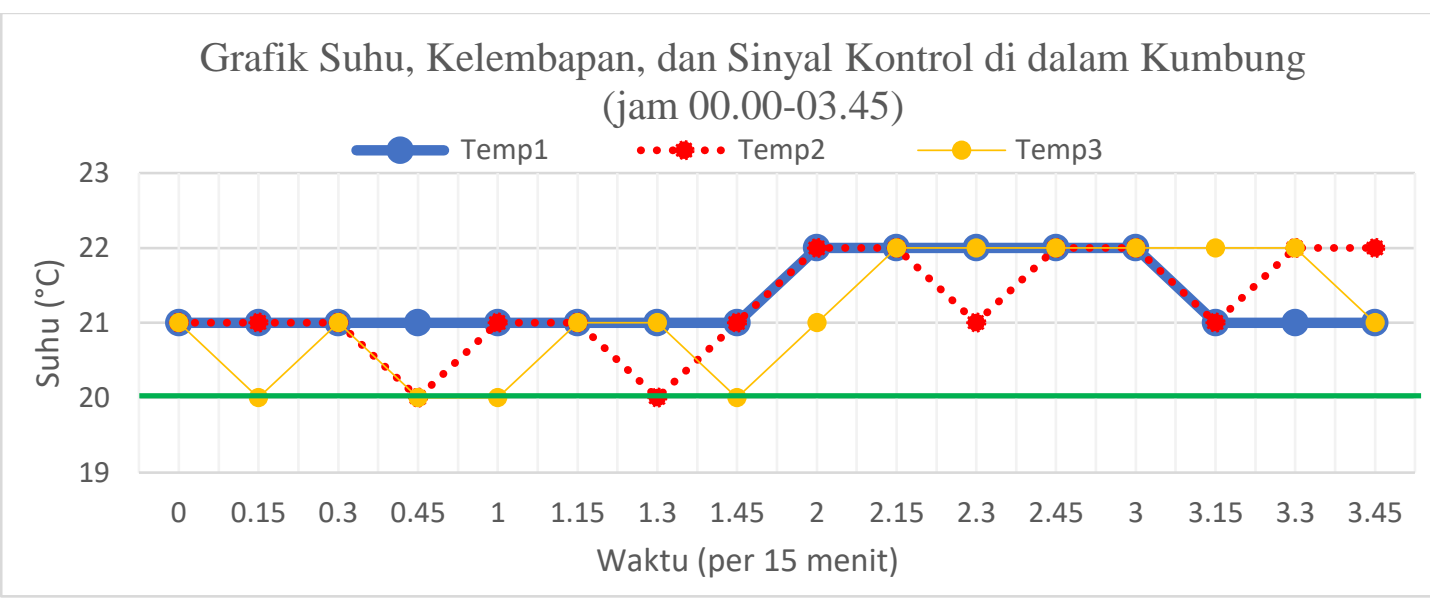




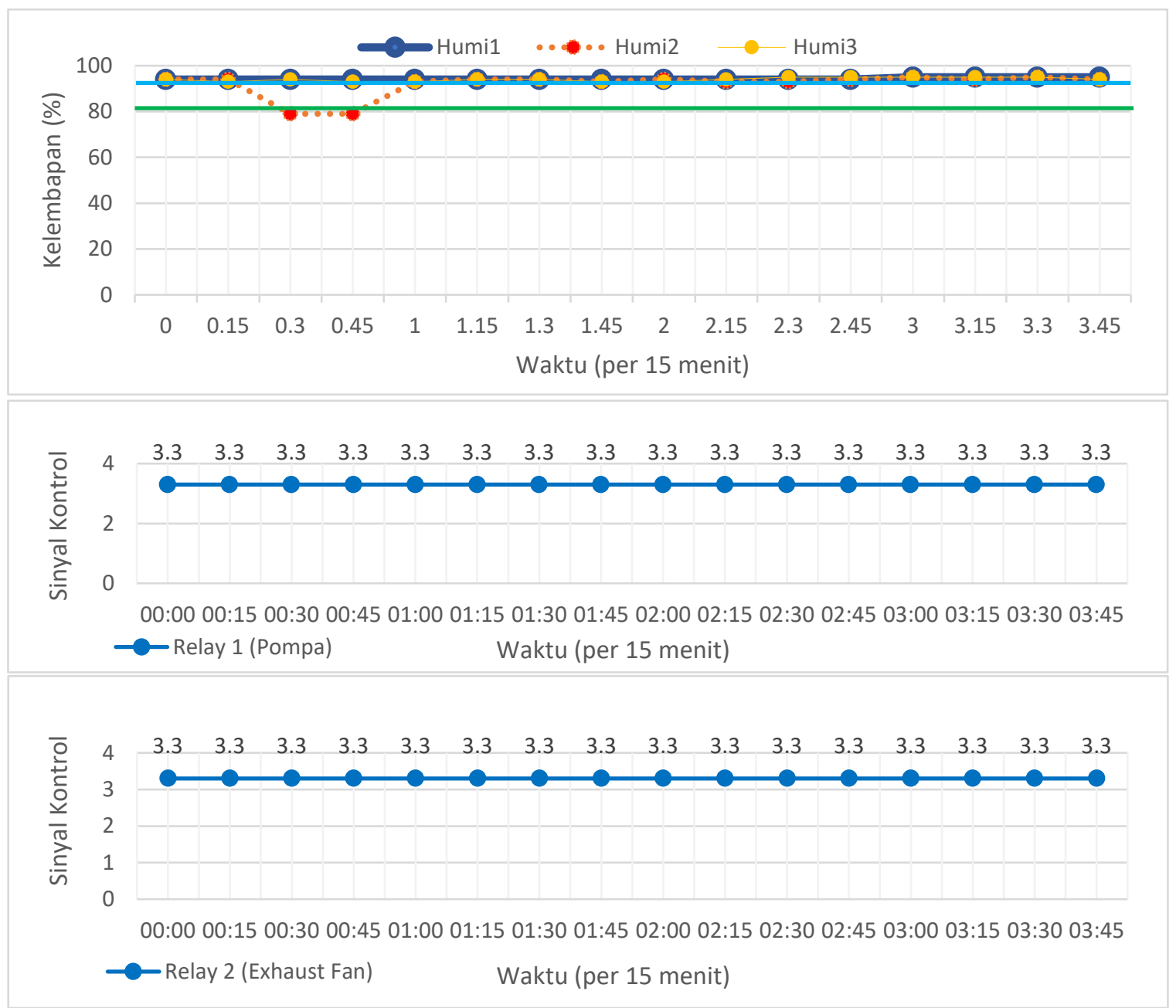

Gambar 11. Grafik Suhu, Kelembapan, dan Sinyal Kontrol dalam Kumbung Jamur Tiram Putih (00.00-03.45)

Dilihat dari grafik pada Gambar 12, suhu cenderung masuk ke dalam range setpoint yang dibutuhkan oleh jamur tiram putih. Sedangkan kelembapan di dalam kumbung cendrung melebihi setpoint yaitu di atas $90 \%$. Hal ini terjadi karena pengaruh dari kondisi alam yang mempengaruhi keadaan di dalam kumbung jamur tiram putih. Sinyal kontrol yang dihasilkan baik untuk relayl (pompa) dan relay2 (exhaust fan) berlogika HIGH (3.3 V) yang berarti relay dalam kondisi OFF atau normally close.

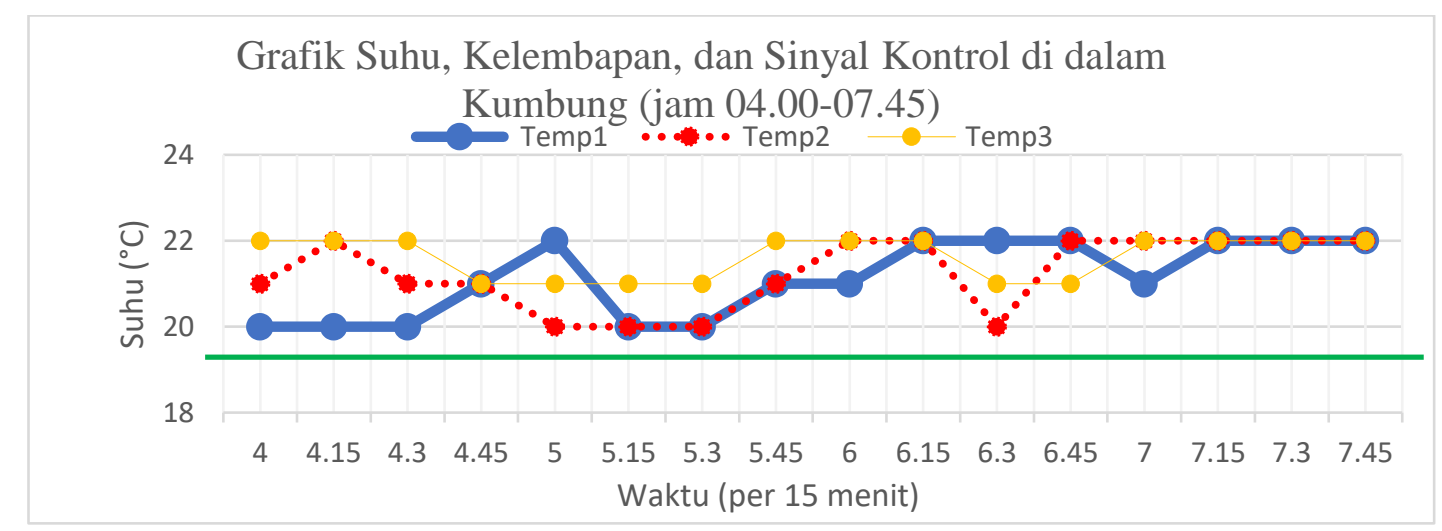




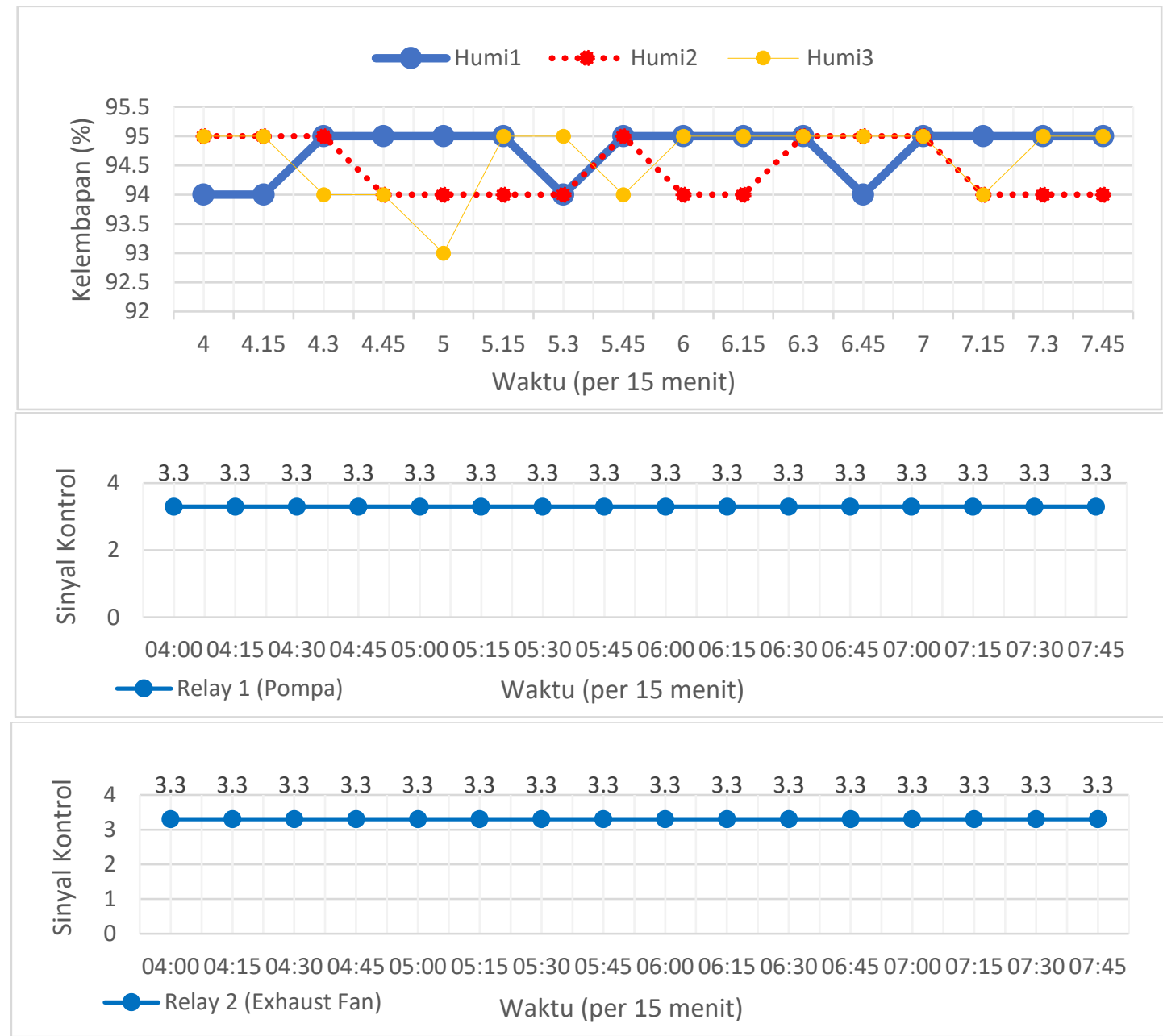

Gambar 12. Grafik Suhu, Kelembapan, dan Sinyal Kontrol di Dalam Kumbung Jamur Tiram Putih (04.00-07.45)

Dari grafik pada Gambar 13, suhu mulai naik dari T1 hingga T2 karena pengaruh intensitas panas cahaya matahari yang mulai meningkat sehingga exhaust fan menyala (logic LOW). Suhu akhirnya melewati batas atas (garis biru) dari setpoint sehingga exhaust fan mati (logic HIGH) dan pompa mulai menyala (logic $L O W$ ) dari T2 hingga T3. Sedangkan kelembapan juga menurun dari T2 hingga T3.

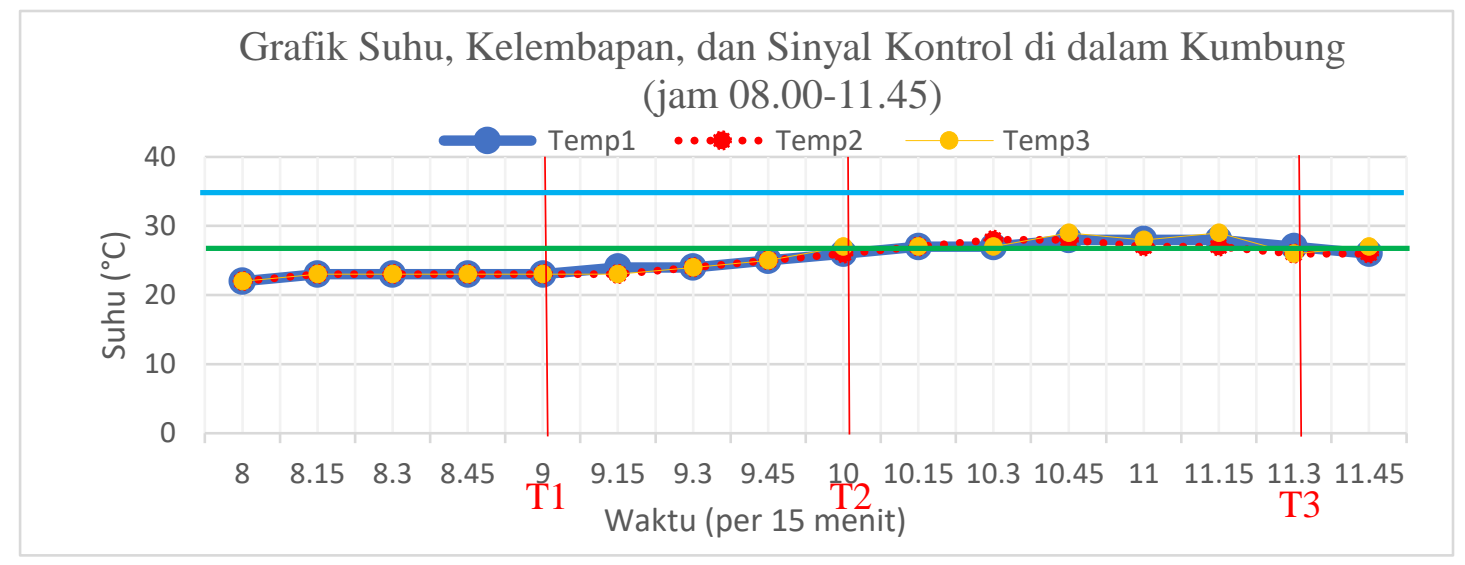




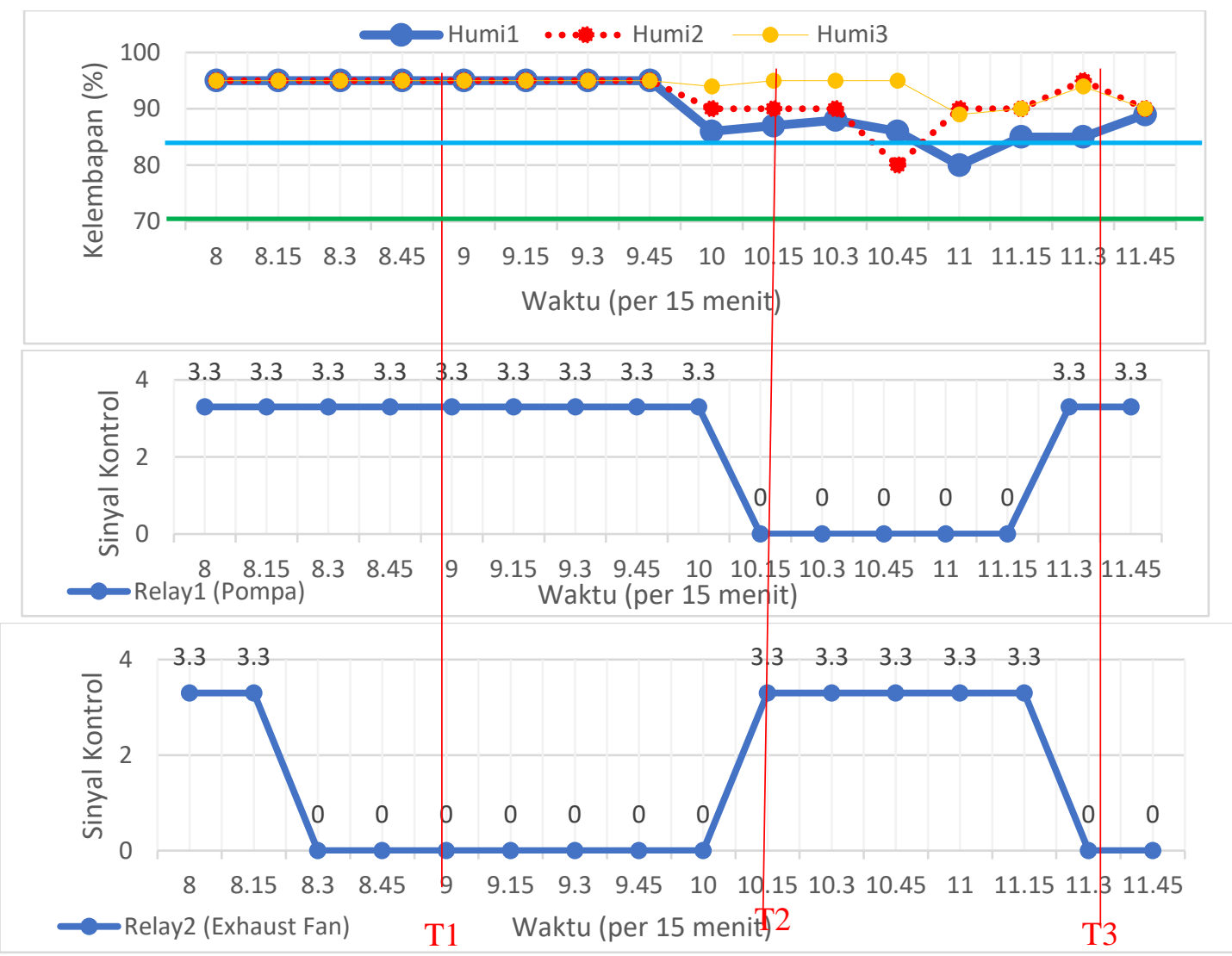

- Gambar 13. Grafik Suhu, Kelembapan, dan Sinyal Kontrol di Dalam Kumbung Jamur Tiram Putih (08.00-11.45)

Hasil grafik pada Gambar 14 menunjukkan suhu terlihat berosilasi pada batas atas (garis biru) setpoint sehingga pompa dan exhaust fan menyala (logic LOW) dan mati (logic HIGH) seiring mengikuti naik dan turunnya suhu. Keadaan suhu tetap stabil meskipun berada sedikit di batas atas setpoint. Sedangkan kelembapan cenderung masuk ke dalam range setpoint. Pada rentang waktu ini, sistem berhasil membuat keadaan di dalam kumbung agar sesuai dengan kebutuhan jamur Tiram Putih. Sedangkan pada penelitian yang dilakukan oleh Sri Waluyo [3], terdapat deviasi suhu di luar setpoint. Suhu di atas batas atas setpoint pada pukul 13.00 - 16.00 akibat dari intensitas cahaya matahari ( \pm 65000 lux) dan suhu yang tinggi $\left(33^{\circ} \mathrm{C}\right)$ ditambah dengan panas hasil respirasi dari jamur yang dibudidayakan yang menyebabkan tingginya suhu di dalam kumbung. Upaya penurunan suhu dilakukan dengan penggunaan inhaust fan dan exhaust fan. Di samping itu, penurunan suhu dengan menyemprotkan air dalam kumbung juga belum mampu menurunkan suhu pada batas maksimum yang diinginkan. Meskipun demikian, hasil pengamatan menunjukkan, deviasi suhu di atas batas atas masih dapat ditoleransi karena jamur tiram masih dapat tumbuh pada suhu tersebut berdasarkan referensi [1]. 


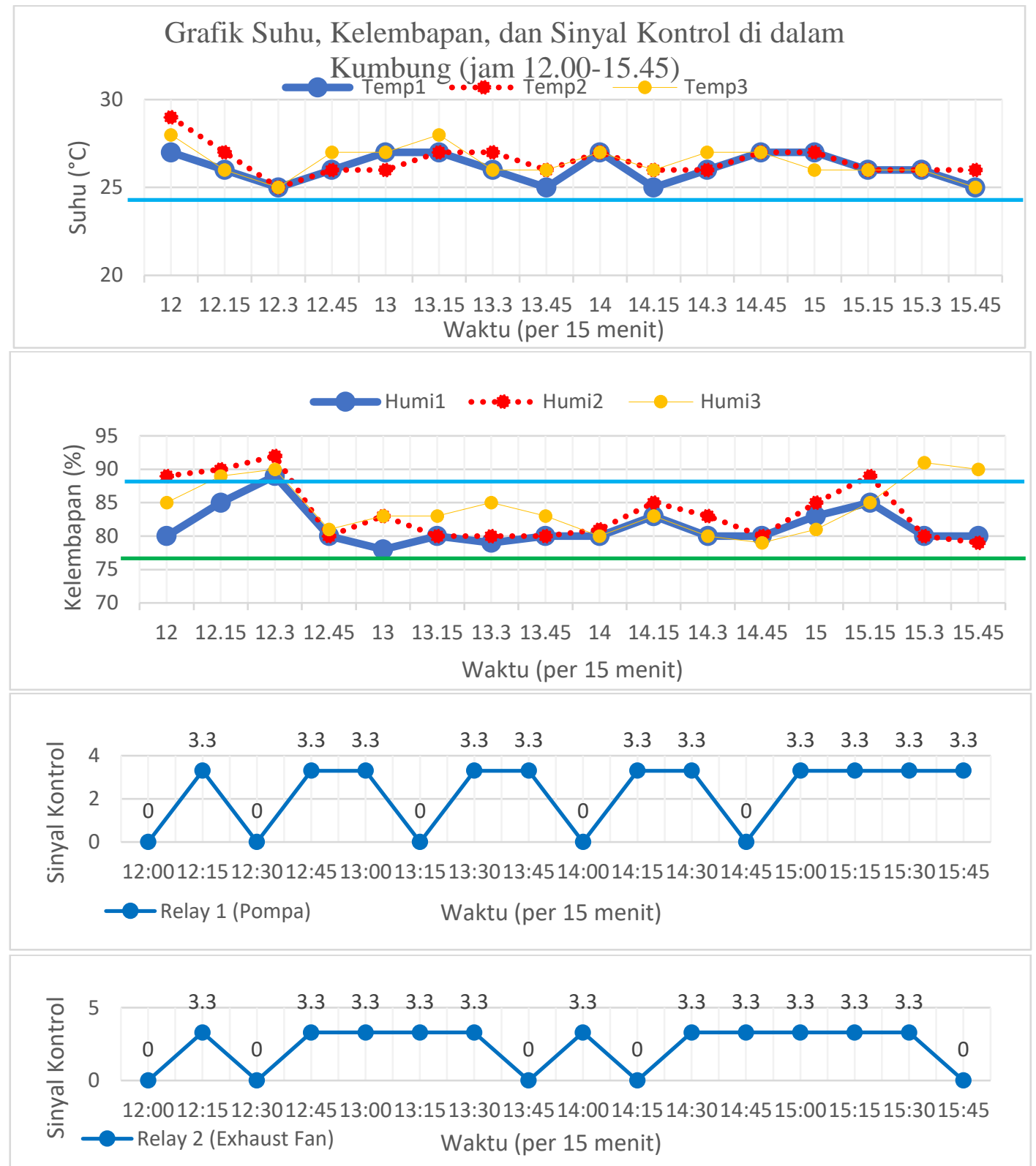

Gambar 14. Grafik Suhu, Kelemabapan, dan Sinyal Kontrol dalam Kumbung Jamur Tiram Putih $(12.00-15.45)$

Grafik pada Gambar 15, suhu lama-kelamaan masuk ke dalam range setpoint karena intensitas panas cahaya matahari mulai menurun, sehingga suhu juga mulai menurun. kelembapan juga meningkat karena terpengaruh keadaan alam di dalam kumbung. 


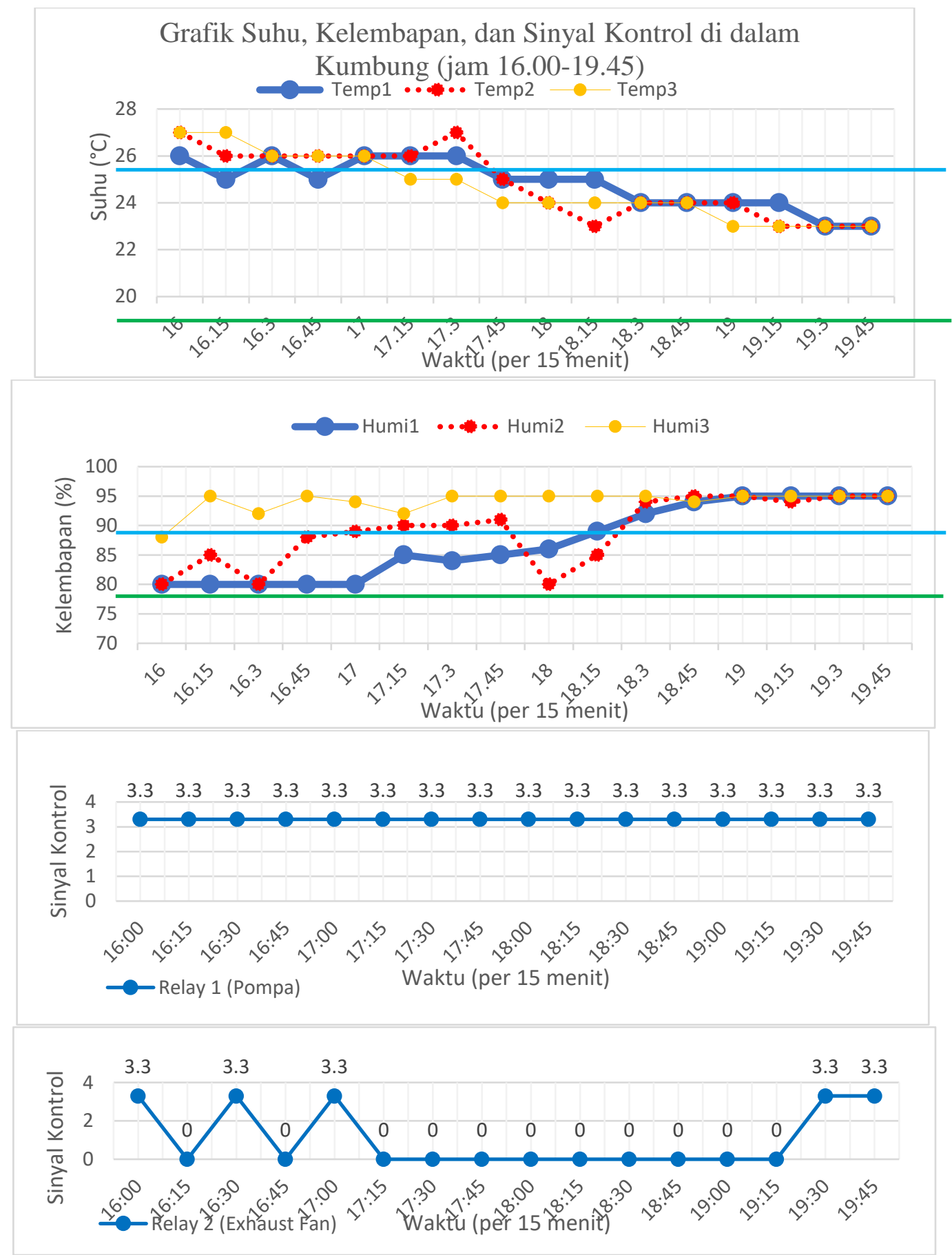

ם Gambar 15. Grafik Suhu, Kelembapan, dan Sinyal Kontrol di Dalam Kumbung Jamur Tiram Putih $(16.00-19.45)$

Dari grafik pada Gambar 16, suhu masuk ke dalam range setpoint yang dibutuhkan jamur tiram putih. Kelembapan naik melebihi batas atas (garis biru) karena pengaruh dari keadaan alam. 


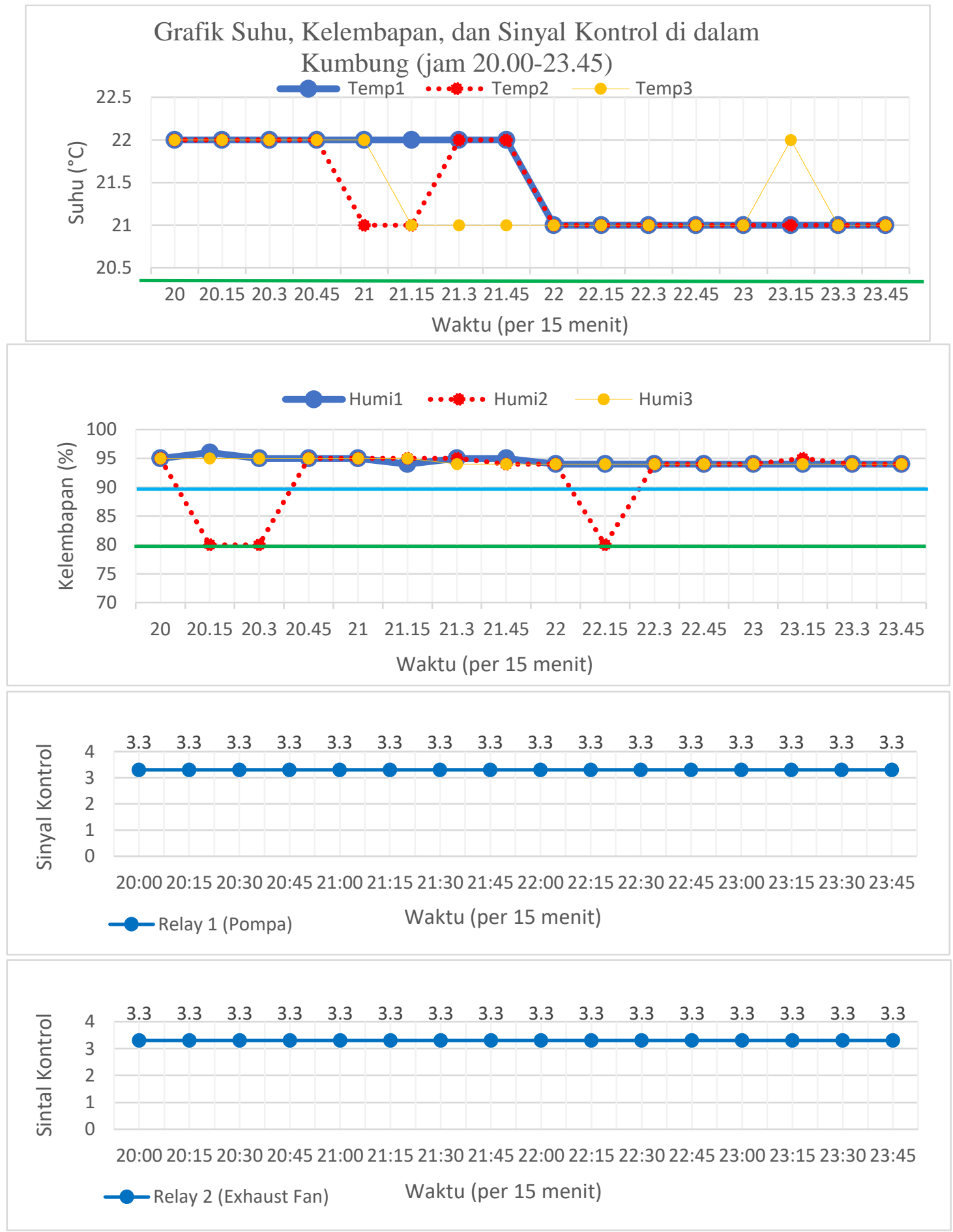

Gambar 16. Grafik Suhu, Kelembapan, dan Sinyal Kontrol di Dalam Kumbung Jamur Tiram Putih (20.00-23.45)

Berikut adalah grafik yang menunjukkan intensitas cahaya setelah dikontrol oleh sistem di dalam kumbung jamur Tiram Putih. Batas atas setpoint ditandai dengan garis warna biru (640 lux). Sedangkan batas bawah setpoint ditandai dengan faris warna hijau (200 lux). Pada Gambar 17, lampu menyala karena intensitas cahaya di dalam kumbung berada di bawah batas bawah setpoint. 


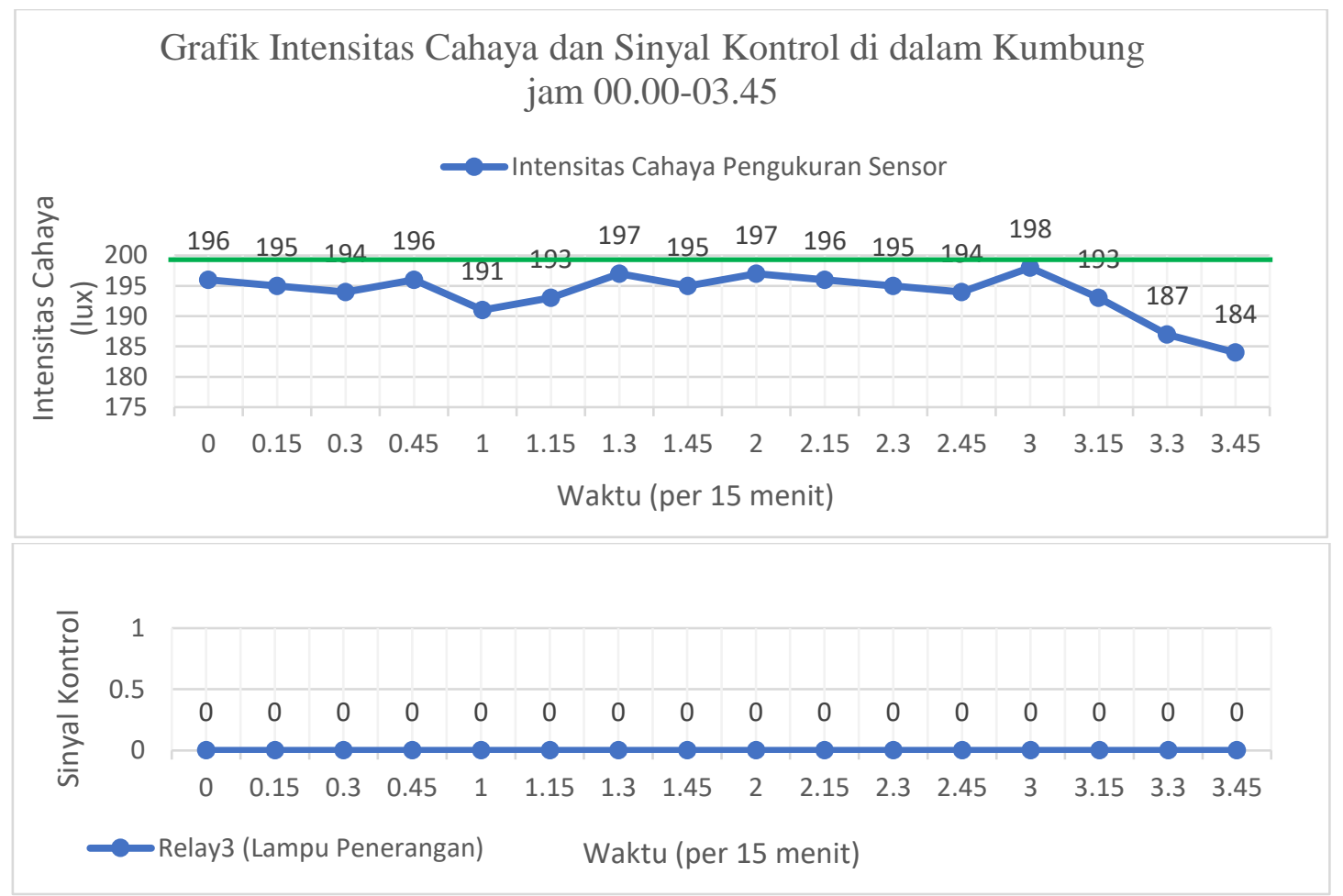

- Gambar 17. Grafik Intensitas Cahaya dan Sinyal Kontrol (Lampu Penerangan) di dalam Kumbung (00.00-03.45)

Dilihat pada Gambar 18, sistem mulai memadamkan lampu pada saat T1 hingga T2, karena intensitas cahaya telah melewati batas bawah. Lampu akan terus padam selama intensitas lampu berada pada differential gap hysteresis (batas atas 640lux dan batas bawah 200lux).

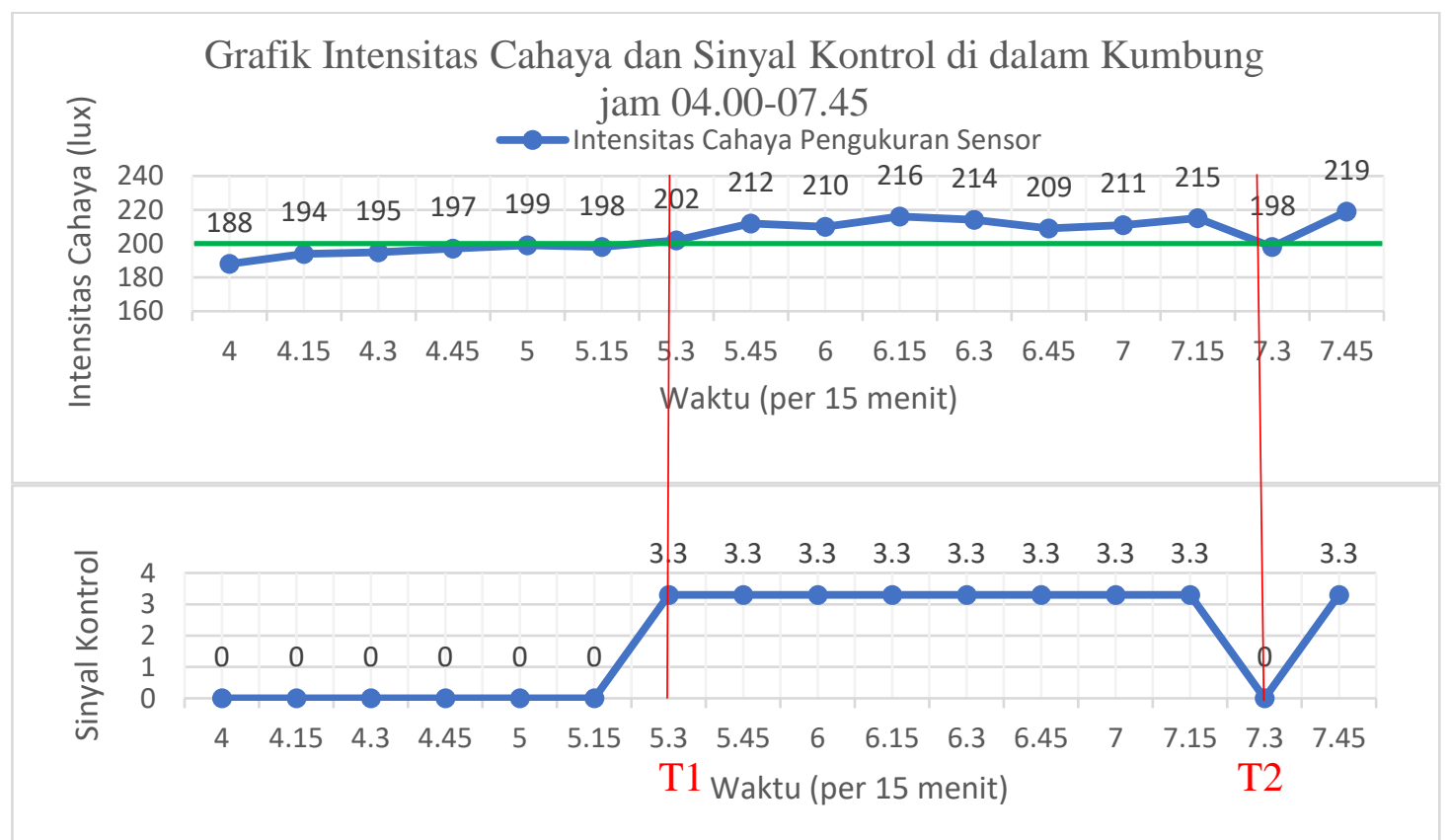

- Gambar 18. Grafik Intensitas Cahaya dan Sinyal Kontrol (Lampu Penerangan) di dalam Kumbung (04.00-07.45)

Dilihat pada Gambar 19, keadaan intensitas cahaya kumbung mulai terang, sehingga pengaruh dari cahaya matahari sudah cukup untuk mengganti penerangan dari lampu. Sehingga sinyal kontrol menghasilkan logika $H I G H(3.3 \mathrm{~V})$. 


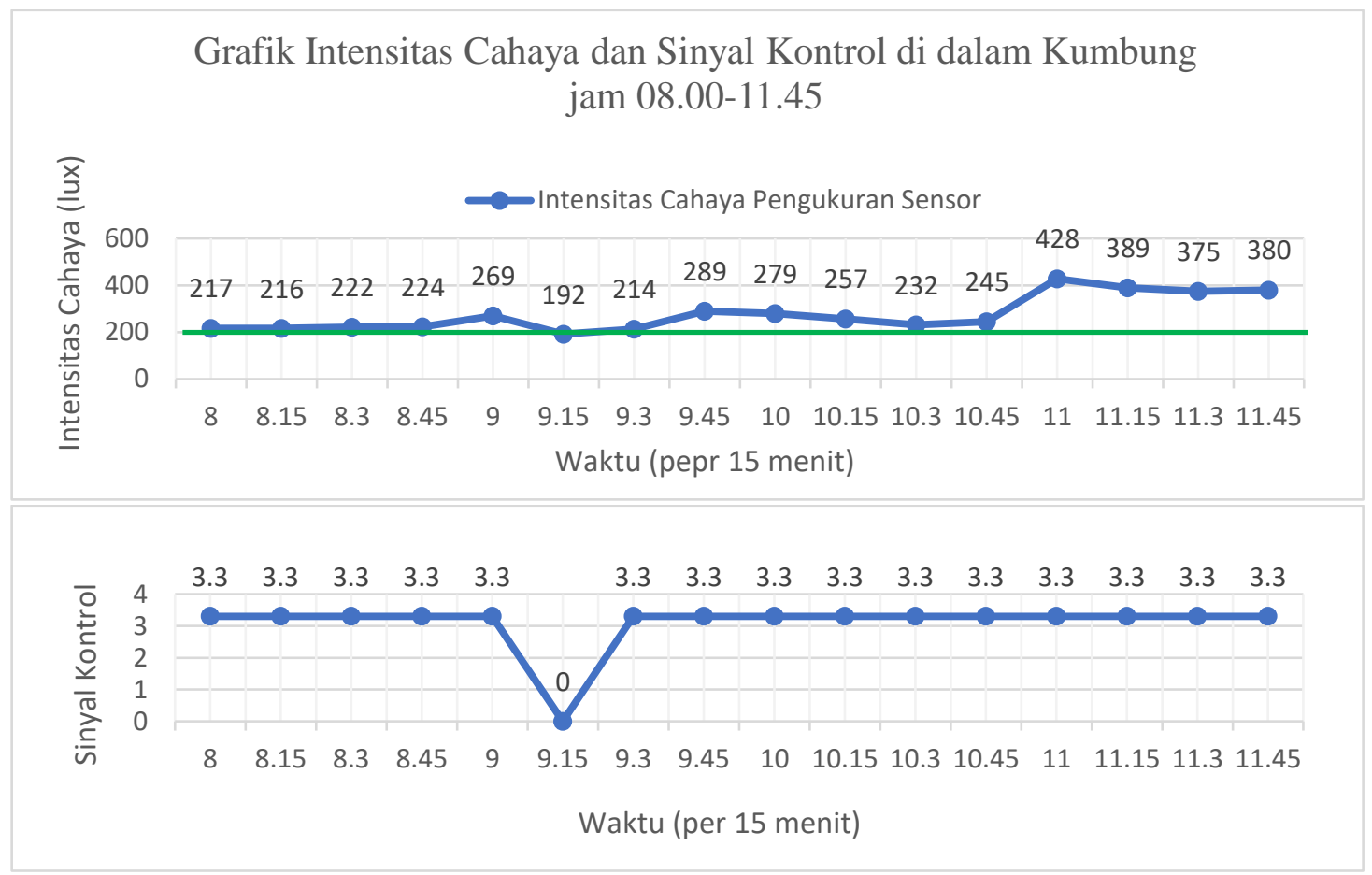

- Gambar 19. Grafik Intensitas Cahaya dan Sinyal Kontrol (Lampu Penerangan) di dalam Kumbung (08.00-11.45)

Saat kumbung mencapai keadaan pada siang hari, intensitas cahaya semakin meningkat karena dipengaruhi oleh sinar matahari yang masuk ke dalam kumbung. Hal ini dapat dilihat pada Gambar 20.

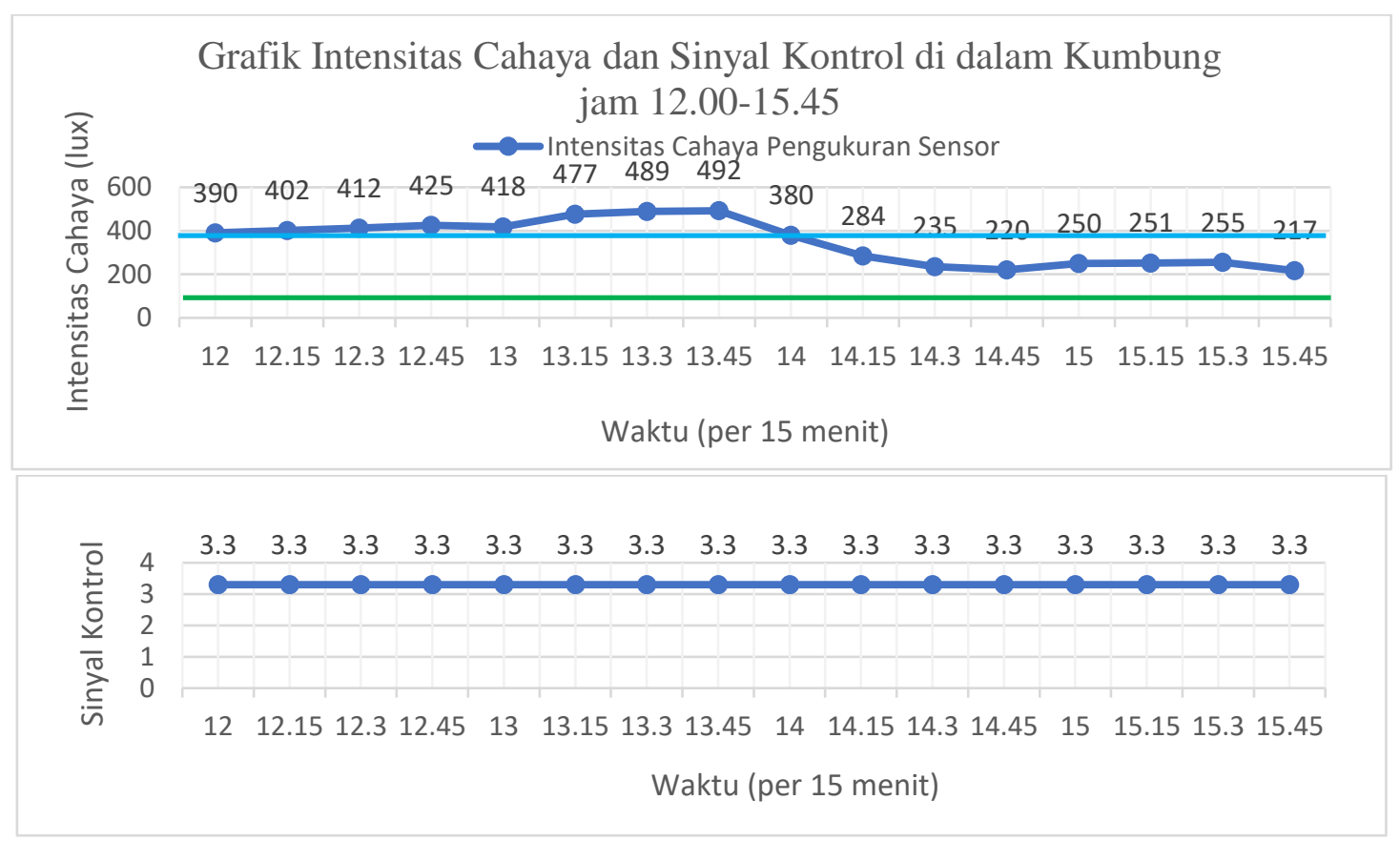

- Gambar 20. Grafik Intensitas Cahaya dan Sinyal Kontrol (Lampu Penerangan) di dalam Kumbung (12.00-15.45)

Dilihat pada Gambar 21, intensitas cahaya di dalam kumbung terjaga karena dipengaruhi oleh cahaya lampu 


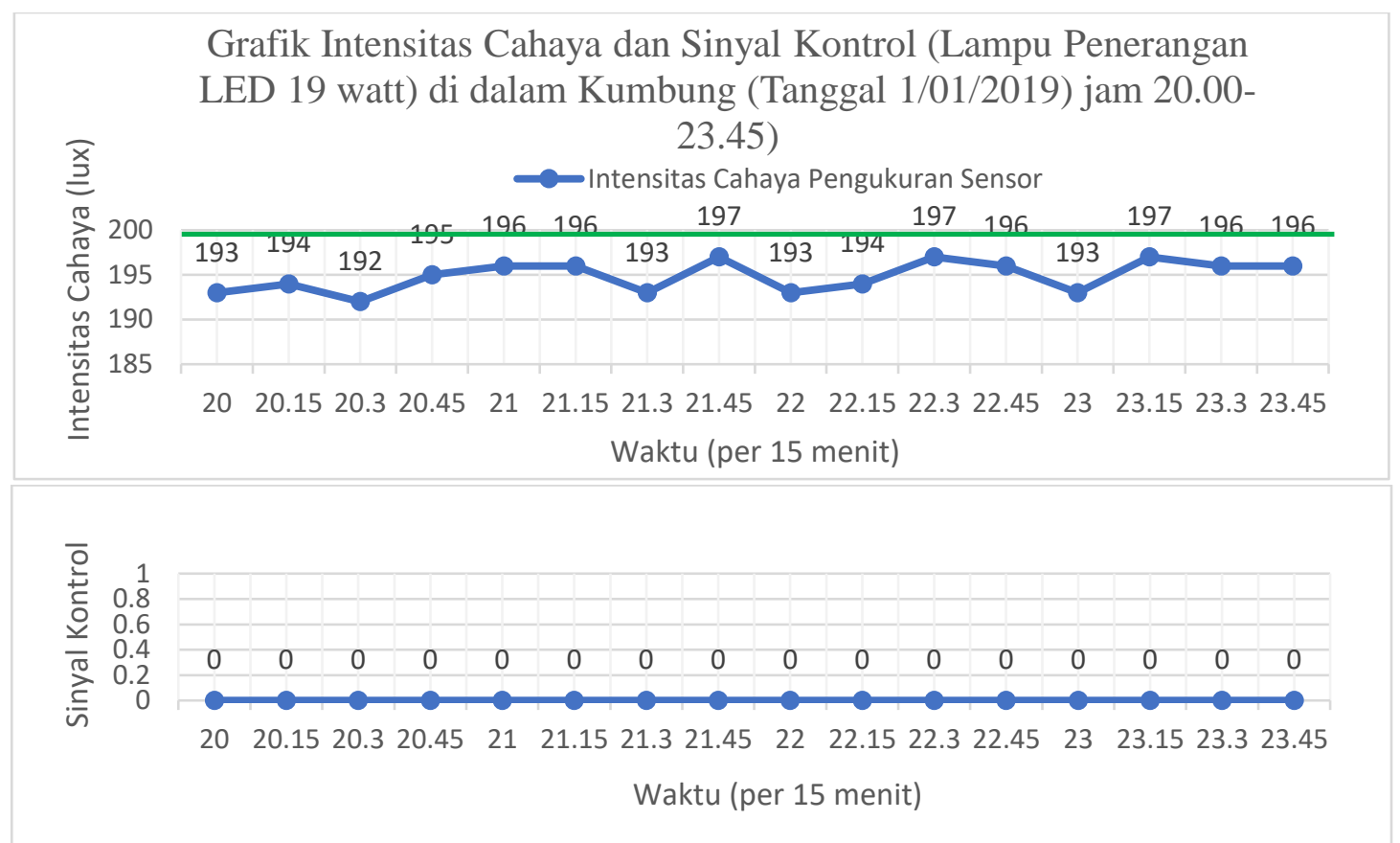

- Gambar 21. Grafik Intensitas Cahaya dan Sinyal Kontrol (Lampu Penerangan) di dalam Kumbung (20.00-23.45)

\section{KESIMPULAN}

Sistem pemantau dan kontrol suhu, kelembapan, dan intensitas cahaya kumbung jamur Tiram Putih berbasis Internet of Things (IoT) berhasil direalisasikan. Penentuan letak titik-titik sensor menggunakan Finite Element Method menunjukkan dapat mewakili kondisi di dalam kumbung jamur Tiram Putih. Hasil uji coba menunjukkan sistem berhasilkan menciptakan keadaan suhu, kelembapan, dan intensitas cahaya yang dibutuhkan oleh jamur dengan error suhu sebesar $2^{\circ} \mathrm{C}$, kelembapan $5 \%$, dan intensitas cahaya 10 lux. Aplikasi Blynk berhasil menampilkan hasil pengukuran sensor di dalam kumbung jamur Tiram Putih.

\section{DAFTAR PUSTAKA}

[1] N.M Djarijah dan A.S Djarijah. "Budi Daya Jamur Tiram”. Yogyakarta : Kanisius. 2001.

[2] A. Nugroho, M. F. K. Asyroh, A. Pangestu, B. Wulandari . "Pengatur Suhu dan Kelembapan Kumbung Jamur Otomatis". ELINVO (Electronics, Informatics, and Vocational Education). 2018.

[3] S. Waluyo, R. E. Wahyono, B. Lanya, M. Telaumbanua. "Pengendalian Temperatur dan Kelembapan dalam Kumbung Jamur Tiram (Pleurotus sp) Secara Otomatis Berbasis Mikrokontroler". Agritech. 2018.

[4] Anisum, N. Bintoro, S. Geonadi. "Analisis Distribusi Suhu dan Kelembapan Udara Dalam Rumah Jamur (Kumbung) Menggunakan Computational Fluid Dynamics (CFD)”. Jurnal Statistik. 2016.

[5] F. Amelia, J. Ferdinand, K. Maria. "Pengaruh Suhu dan Intensitas Cahaya Terhadap Pertumbuhan Jamur Tiram di Tangerang". Biogenesis. 2017.

[6] J. N. Reddy. "An Introduction To Finite Element Method". New York. Department of Mechanical Engineering Texas A \& M University College Station. McGraw-Hill. 2005.

[7] Johnson, D. Curtis. Process Control Instrumentation Technology. Eight Edition. England : PEARSON. 2014. 